
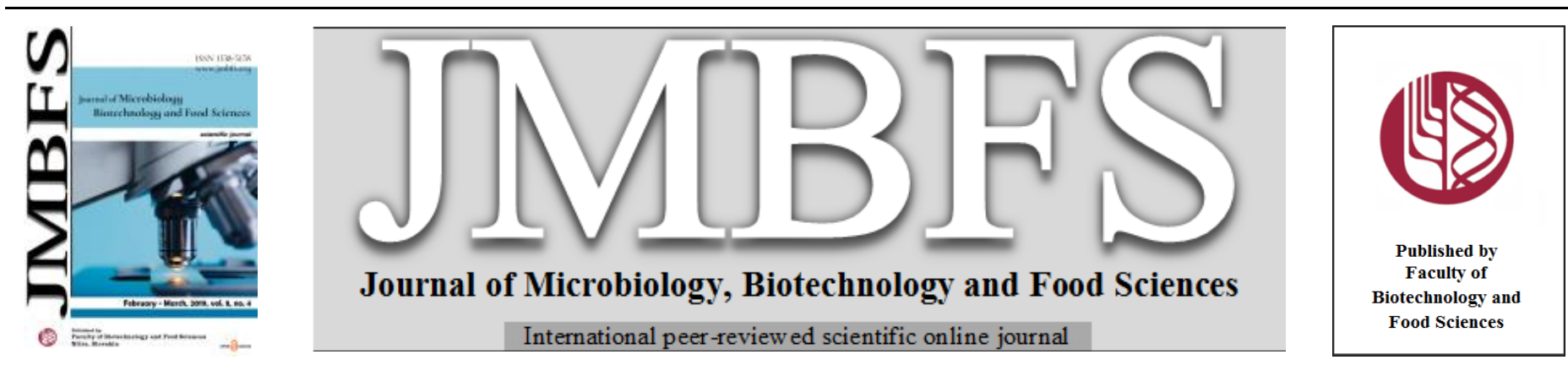

\title{
PRODUCTION AND PHYSICOCHEMICAL PROPERTIES OF THERMOSTABLE, CRUDE CELLULASE FROM ENTEROBACTER CLOACAE IP8 ISOLATED FROM PLANT LEAF LITTERS OF LAGERSTROEMIA INDICA Linn.
}

\author{
Abayomi I. Akintola ${ }^{1}$, Olaoluwa Oyedeji*1, Isaac O. Adewale ${ }^{2}$, Mufutau K. Bakare $^{1}$ \\ Address(es): Olaoluwa Oyedeji, \\ ${ }^{1}$ Obafemi Awolowo University, Faculty of Science, Department of Microbiology, Ile-Ife, Nigeria. \\ ${ }^{2}$ Obafemi Awolowo University, Faculty of Science, Department of Biochemistry and Molecular Biology, Ile-Ife, Nigeria.
}

*Corresponding author: laoluoyedeji@gmail.com

doi: $10.15414 / j m b f s .2019 .8 .4 .989-994$

\section{ARTICLE INFO}

Received 9. 3. 2018

Revised 24. 10. 2018

Accepted 24. 10. 2018

Published 1. 2. 2019

Regular article

OPEN $\partial_{\text {ACCESS }}$

\begin{abstract}
Cellulases have wide applications and biotechnological potentials for various industries. A bacterium producing an extracellular, thermostable cellulase was isolated from plant leaf litters of Lagerstroemia indica Linn, inside a botanical garden. According to morphological, biochemical and physiological characterization, it was tentatively identified as Enterobacter sp. Molecular characterization, using the 16S rRNA gene sequencing was used to confirm the identity of the bacterium as Enterobacter cloacae IP8. Effects of some cultural factors such as carbon and nitrogen sources, $\mathrm{pH}$ and temperature, on cellulase production from the bacterium, were investigated. Some physicochemical properties of the crude cellulase from E. cloacae IP8 were determined to evaluate its potentials for industrial applications. The maximum yield of cellulase $(10.78 \mathrm{U} / \mathrm{mL})$ was at $28 \mathrm{~h}$ of incubation using carboxymethyl cellulose (CMC) $(1.5 \%, \mathrm{w} / \mathrm{v})$, peptone $(2.0 \%, \mathrm{w} / \mathrm{v})$, inoculum size $(1.0 \%, \mathrm{v} / \mathrm{v}), \mathrm{pH}$ and temperature of 7.0 and $45{ }^{\circ} \mathrm{C}$, respectively, and agitation speed $150 \mathrm{rpm}$. The crude cellulase exhibited optimum activity at $60{ }^{\circ} \mathrm{C}$, retaining $75.0 \%$ of its maximal activity at $70{ }^{\circ} \mathrm{C}$. It had optimum $\mathrm{pH}$ of 7.0, retaining $58.0 \%$ of its original activity at acidic $\mathrm{pH} 5.0$. Metal ions $\mathrm{Na}^{+}, \mathrm{Ca}^{2+}$ and $\mathrm{Mg}^{2+}$ remarkably enhanced activity of the cellulase while $\mathrm{K}^{+}$and EDTA inhibited activity of the cellulase from E. cloacae IP8. The characteristics of the cellulase from E. cloacae IP8 revealed the enzyme as being thermostable and an acidic to neutral metalloenzyme. Therefore, the enzyme from this strain could be applied in industrial applications such as lignocellulosic biomass conversion into fuel and other value added products.
\end{abstract}

Keywords: Enterobacter cloacae; Cellulase; Production; Characterization; Thermostable; Physicochemical

\section{INTRODUCTION}

Cellulose is the most abundant biopolymer in nature and forms the major component of plant biomass (Yin et al., 2010; Sadhu et al., 2013; Kilo et al., 2016). It is a linear polysaccharide polymer of $\beta-1,4$-glycosidic bonds and its crystalline structure is stabilized by intramolecular and intermolecular hydrogen bonds (Hikaru et al., 2008). Globally, plants are estimated to produce $4 \times 10^{9}$ tons of cellulose annually (Narasimha et al., 2006; Yin et al., 2010). Most of the cellulose exist as wastes which may be agricultural, urban or industrial in origin and includes straw, corn cobs, wood wastes, peat, bagasse and waste paper (Reddy et al., 2015). These cellulosic wastes exist abundantly as organic wastes which tend to accumulate in the environment. However, they could be utilized more efficiently by being converted to fermentable sugars which act as carbon sources for the production of various products of commercial interests such as fuels and chemicals (Chen et al., 2007; Kuhad et al., 2011). The natural degradation of cellulose is carried out by cellulolytic microorganisms, which form an important part of the biosphere carbon cycle. Cellulolysis, which is the complete hydrolysis of the cellulose polymer to glucose is carried out by the synergistic action of three cellulolytic enzyme system (Acosta-Rodriguez et al., 2005; Eveleigh et al., 2005; Kuhad et al., 2011). $\beta-1,4-$ endoglucanase (EC 3.2.1.4) randomly attacks the internal $\beta-1,4$-glycosidic bonds along a cellulose chain, resulting in glucan chains of different lengths; the $\beta-1,4$-exoglucanase (EC 3.2.1.91) acts on the ends of the cellulose chain and releases $\beta$-cellobiose as the end products while the $\beta$-1,4-glucosidase (EC 3.2.1.21) specifically hydrolyzes $\beta$ cellobiose to two glucose molecules. Biological oxidation of cellulose by cellulases is preferred for industrial purposes due to high yields of desired hydrolytic products with minimal by-products (Parry et al., 2001). Effective utilization of cellulosic materials through bioprocesses will be an important key to overcome the shortage of foods, feed, and fuels which the world may face in the near future, because of the explosive increase in human population (Ohmiya et al., 1997). Cellulases have wide applications and biotechnological potentials for various industries including chemical, fuel, food, brewery, animal feed, textile and pulp and paper industries (Bhat, 2000; Gilna and Khaleel, 2011; Karnouri et al., 2014; Ladeira et al., 2015). Some industrial processes for which cellulases find useful applications are clarification and liquefaction of fruit and vegetable juices, biopolishing of cotton and other cellulosic fabrics, improvement of nutritional and digestibility of animal feeds and ethanol fuel production (De Carvalho et al., 2008; Gaur and Tiwari, 2015; Behera et al., 2017). Enzyme production is closely controlled in microorganisms and therefore these controls can be carefully exploited to enhance enzyme productivity. Cellulase yield depends on a complex relationship involving a variety of factors like $\mathrm{pH}$, temperature, incubation period, carbon and nitrogen sources (Immanuel et $\boldsymbol{a l}$., 2006). To establish a successful fermentation process, microorganisms are exploited for the overproduction of the desired metabolite. An elaborate investigation is thus necessary to establish the optimum conditions necessary for scale up of of enzyme production in an individual fermentation process. Studies have shown a direct proportion between production costs of cellulase and productivity of enzyme producing microbial strains (Omojasola $\boldsymbol{e t}$ al., 2008). Such processes would assist in food and animal feed processing, solve modern waste disposal problem and reduce drastically man's dependence on fossil fuels by providing a convenient and renewable source of energy in the form of glucose which can be used for production of ethanol, organic acids and other commercially useful chemicals (Makoi and Ndakidemi, 2008). The conversion of cellulosic biomass by microorganisms is thus a potentially sustainable approach to developing novel bioprocesses and products (Kuhad et al., 2011). Cellulase research has been concentrated mostly on fungi but there is increase in cellulase production by bacteria due to their higher growth rate, thermostability and alkaline stablility properties (Nagendran et al., 2009; Acharya and Chaudhuri, 2012). Cellulose-degrading bacteria have been isolated from variety of sources such as soils, decayed plant materials, hot springs, organic matter, faeces of ruminants and composts and the search for bacteria with improved cellulolytic activities has been ongoing (Ray et al., 2007; Doi, 2008). There are reports of production of thermostable cellulases from several bacteria strains isolated from diverse sources. These include Bacillus vallismortis RG-07 from 
soil (Gaur and Tiwari, 2015), Bacillus licheniformis Vic. From geotherma wells (Kilo et al., 2016), B. licheniformis 380 from compost (De Marco et al., 2017) and $B$. licheniformis $\mathrm{C} 55$ from solid waste carrageenan (Listyaningrum $\boldsymbol{e}$ al., 2018). The objective of our study was the isolation and screening of cellulolytic bacteria from plant leaf litters of Lagerstroemia indica Linn Optimization of different nutritional and environmental parameters for maximum cellulase production from selected bacterium and characterization of produced thermostable cellulase were then carried out.

\section{MATERIAL AND METHODS}

\section{Isolation and maintenance of bacteria}

Bacterial strains were isolated from dumpsites of plant leaf litters of Lagerstroemia indica Linn by using serial dilutions and pour plate technique. Aliquot $(100 \mu \mathrm{L})$ of each diluted sample was spread on correspondingly labelled sterile nutrient agar plates which were incubated at $45{ }^{\circ} \mathrm{C}$ for $48 \mathrm{~h}$ (Apun et al. 2000). Representative bacterial colonies were purified by repeated streaking on nutrient agar and then preserved at $4{ }^{\circ} \mathrm{C}$ on nutrient agar slants for further identification and screening for cellulase production.

\section{Screening of bacterial isolates}

Pure cultures of bacterial isolates were individually streaked on carboxymethy cellulose agar (CMCA) plates consisting of yeast extract $\left(0.2 \%\right.$, w/v), $\mathrm{KH}_{2} \mathrm{PO}_{4}$ $(0.1 \%, w / v), \mathrm{MgSO}_{4} 7 \mathrm{H}_{2} \mathrm{O}(0.5 \%, \mathrm{w} / \mathrm{v}), \mathrm{NaCl}(0.075 \%, \mathrm{w} / \mathrm{v})$, peptone $(2.0 \%$, $\mathrm{w} / \mathrm{v})$, agar $(1.5 \%, \mathrm{w} / \mathrm{v})$ and high viscosity carboxymethyl cellulose $(0.5 \%, \mathrm{w} / \mathrm{v})$ The CMCA plates were incubated at $55{ }^{\circ} \mathrm{C}$ for $48 \mathrm{~h}$. These plates were then flooded with Congo red $(0.1 \%)$ for $15 \mathrm{~min}$ at room temperature and then destained with $1 \mathrm{M} \mathrm{NaCl}$ solution. Clear halo zone surrounding bacterial colonies was indicative of cellulose hydrolysis and measured in centimeters (Wood and Bhat, 1998). Endo-1,4- $\beta$ - glucanases $(\mathrm{Cx})$ producing activities of the isolates were estimated by the carboxymethyl cellulose hydrolysis capacity (HC value: ratio of diameter of clear zone and line of streak) on the cellulose congo-red agar (Lu et al., 2005). Isolates with high $\mathrm{HC}$ values were selected for identification and cellulase production using submerged fermentation system.

\section{Characterization and identification of cellulolytic bacterium}

Identification of bacterial isolate with the highest cellulolytic activity was carried out using phenotypic methods involving morphological, biochemical and physiological characterizations (Harrigan and McCance, 1976). Molecular characterization was then carried out to confirm the identity of the cellulolytic bacterium. The method was based on the 16S rRNA gene nucleotide sequencing and comparison to the sequences in National Centre for Biotechnology Information (NCBI) database (Bethesda, MD, USA). The primers used in this study were f25 (5'-AGAGTTTGATCMTGGCTCAG-3') and r1525 (5'AAGGAGGTGWTCCARCCGCA-3'). The PCR products were analyzed by agarose gel electrophoresis. ABI 3130 x L Genetic Analyzer (Applied Biosystems, California, USA) was used for the nucleotide sequencing. Sequence similarity search of the Genbank data was done using a Basic Alignment Search Tool (BLAST) from the NCBI database (Mangamuri et al., 2012).

\section{Cellulase production}

Cellulase was produced by submerged fermentation $(\mathrm{SmF})$ in Erlenmeyer flasks $(250 \mathrm{~mL})$ containing $100 \mathrm{~mL}$ of basal medium composed of yeast extract $(0.2 \%$, w/v), $\mathrm{KH}_{2} \mathrm{PO}_{4}\left(0.1 \%\right.$, w/v), $\mathrm{MgSO}_{4} 7 \mathrm{H}_{2} \mathrm{O}(0.5 \%, \mathrm{w} / \mathrm{v}), \mathrm{NaCl}(0.075 \%$, w/v), peptone $(2.0 \%, \mathrm{w} / \mathrm{v})$ and high viscosity carboxymethyl cellulose $(0.2 \%, \mathrm{w} / \mathrm{v})$ The medium was inoculated with standardized aqueous suspension of the bacterium from a $24 \mathrm{~h}$ old culture $(3.0 \times 106 \mathrm{CFU} / \mathrm{mL})$. The mixture was incubated at $45{ }^{\circ} \mathrm{C}$ for $48 \mathrm{~h}$ on a rotary shaker at $150 \mathrm{rpm}$. After incubation, the fermentation broth was centrifuged at $6000 \mathrm{rpm}$ for $30 \mathrm{~min}$ at $4{ }^{\circ} \mathrm{C}$ to obtain the cell-free supernatant (CFS) that was collected as the crude enzyme extract and used for cellulase assay.

\section{Cellulase assay}

The $\beta-1,4-$ endoglucanase activity towards carboxymethyl cellulose (CMC) was measured by the appearance of reducing end groups released by the action of the enzymes on the substrate using the method of Somogyi (1952). Mixture of 0.1 $\mathrm{mL}$ of $0.1 \%$, w/v CMC (in $100 \mathrm{mM}$ of phosphate buffer, $\mathrm{pH} 7$ ) with $0.5 \mathrm{~mL}$ of crude enzyme was prepared. Phosphate buffer $(0.85 \mathrm{~mL})$ was added to make the corresponding volume $1.0 \mathrm{~mL}$ and the resulting mixture incubated at $55{ }^{\circ} \mathrm{C}$ for 20 min. The reaction was terminated by the addition of $1.0 \mathrm{~mL}$ combined copper reagent. The reaction mixture was heated at $100{ }^{\circ} \mathrm{C}$ for $20 \mathrm{~min}$ in a boiling water bath. The tubes were cooled rapidly under running tap water and arsenomolybdate reagent $(1.0 \mathrm{~mL})$ was added to all the tubes while shaking. The mixtures were diluted with distilled water $(7.0 \mathrm{~mL})$. The optical density (O.D) was read at $540 \mathrm{~nm}$ against blank. The amount of reducing sugars produced was interpolated from the glucose standard curve. One unit of cellulase activity was expressed as the amount of enzyme that liberated reducing sugar equivalent to 1 $\mu \mathrm{g}$ of glucose per milliliter per minute under the specified assay condition.

\section{Bacterial growth and cellulase production}

The time course of cellulase production was determined and compared with bacterial growth according to the method described by de Souza and Martins (2001), with appropriate modifications. The growth curve and enzyme production for the bacterium was determined by inoculating a $250 \mathrm{~mL}$ enzyme fermentation medium with $2.5 \mathrm{~mL}$ standardized inoculum of bacterium in an Erlemenyer flask. The culture medium was incubated at $45^{\circ} \mathrm{C}$ for $48 \mathrm{~h}$ with agitation at $150 \mathrm{rpm}$. At $2 \mathrm{~h}$ intervals, $5.0 \mathrm{~mL}$ samples were collected aseptically for a period of $48 \mathrm{~h}$. The optical density of the culture was checked at $680 \mathrm{~nm}$ using spectrum lab $23 \mathrm{~A}$ spectrophotometer and recorded as the cell optical density. This was then centrifuged at $6000 \mathrm{rpm}$ for $30 \mathrm{~min}$ to obtain cell-free supernatant (CFS). The cellulase activity of the clear supernatant was then measured.

\section{Effect of nutritional and environmental factors on cellulase production}

\section{Effect of pH on cellulase production}

Fermentation medium $(50.0 \mathrm{~mL})$ adjusted to different $\mathrm{pH}$ conditions 4.0 to 10.0 were each inoculated with $0.5 \mathrm{~mL}$ of standardized bacterial inoculum and the culture incubated at $45{ }^{\circ} \mathrm{C}$ for $28 \mathrm{~h}$ with agitation at $150 \mathrm{rpm}$. After incubation, cells were removed by centrifugation and the amount of cellulase present in supernatant was quantified.

\section{Effect of temperature on cellulase production}

Influence of temperature on cellulase production was determined by varying the incubation temperature from 35 to $60{ }^{\circ} \mathrm{C}$, at $\mathrm{pH} 7.0$ and agitation speed of 150 $\mathrm{rpm}$. After incubation, cells were removed by centrifugation and the amount of cellulase present in supernatant was quantified.

\section{Effect of carbon sources on cellulase production}

The effect of various carbon sources on cellulase production from bacterium was studied by replacing high viscosity carboxylmethyl cellulose $(0.2 \%$, w/v) with different sugars: lactose, soluble starch, glucose, sucrose, galactose, and mannitol. The fermentation medium, previously adjusted to $\mathrm{pH} 7.0$, was inoculated with $0.5 \mathrm{~mL}$ of the cell suspension and the culture incubated for $28 \mathrm{~h}$ at $45^{\circ} \mathrm{C}$ with agitation at $150 \mathrm{rpm}$. The supernatant obtained was then tested for cellulase activity.

\section{Effect of different concentrations of carboxymethyl cellulose on cellulase} production

The effect of different concentrations of carboxymethyl cellulose $(0.5,1.0,1.5$, 2.0 and $2.5 \%, \mathrm{w} / \mathrm{v}$ ) on cellulase production from bacterium was studied. The culture was incubated for $28 \mathrm{~h}$ at $45{ }^{\circ} \mathrm{C}$ with agitation at $150 \mathrm{rpm}$. The supernatant was obtained and cellulase production was determined.

\section{Effect of nitrogen sources on cellulase production}

The effect of different nitrogen sources peptone, ammonium sulphate, potassium nitrate, ammonium chloride and yeast extract at $2.0 \%$, w/v, separately, on cellulase production from bacterium was studied. The fermentation medium was incubated for $28 \mathrm{~h}$ at $45{ }^{\circ} \mathrm{C}$ with agitation at $150 \mathrm{rpm}$. After incubation, the supernatant obtained was tested for cellulase activity.

\section{Physicochemical characterization of cellulase from $E$. cloacae IP8}

\section{Effect of pH on activity of crude cellulase}

The effect of different $\mathrm{pH}$ conditions on activity of crude cellulase was determined by incubating the crude enzyme extract with $0.1 \mathrm{~mL}$ of $0.1 \%$, w/v CMC prepared in different buffers ( $\mathrm{pH} 4.0$ to 9.0). The cellulase activity was determined according to standard procedure. The $\mathrm{pH}$ was adjusted using $10 \mathrm{mM}$ sodium acetate buffer ( $\mathrm{pH} 4.0$ to 5.5) and $100 \mathrm{mM}$ phosphate buffer (6.0 to 9.0) Incubation was at $45^{\circ} \mathrm{C}$ for $20 \mathrm{~min}$.

\section{Effect of temperature on activity of crude cellulase}

The effect of temperature on activity of crude cellulase was determined by incubating the reaction mixtures at temperature conditions ranging from $35^{\circ} \mathrm{C}$ to $80{ }^{\circ} \mathrm{C}$ for $20 \mathrm{~min}$. Thereafter, the cellulase activity was determined according to the standard procedure earlier described. 


\section{Effect of metal ions and EDTA on activity of crude dellulase}

The effect of metal ions $\left(\mathrm{K}^{+}, \mathrm{Na}^{+}, \mathrm{Mg}^{2+}\right.$ and $\left.\mathrm{Ca}^{2+}\right)$, at different concentrations $(0$ to $200 \mathrm{mM}$, on cellulase activity was determined by adding each metallic ion to the reaction mixture. Effect of ethylenediamine tetraacetic acid (EDTA) on activity of cellulase was determined by incubating different concentrations of EDTA $(0,4,12,15,20,30,50,80,100,120 \mathrm{mM})$ with the reaction mixture. Cellulase activity was determined in each case by following standard assay procedure.

\section{Statistical analysis}

All data were subjected to statistical analysis for determination of mean and standard deviation using SPSS version 16. Experiments were carried out in triplicates.

\section{RESULTS AND DISCUSSION}

\section{Screening and selection of cellulolytic bacterium}

In this study, seven bacterial isolates were obtained from decayed plant leaf litters of Lagerstroemia indica Linn and subjected to screening for cellulolytic activity using the plate method. Among these seven bacterial strains, three were found to exhibit cellulolytic activities out of which the isolate with the highest carboxymethyl cellulose hydrolytic capacity was selected for further studies (Tab 1). Cellulolytic bacteria have been isolated from diverse environments by previous researchers. Gao et al. (2011) reported a cellulolytic bacterium, Vibrio xiamenensis, isolated from mangrove soil in Xiamen, Fujian province of China. Bacterial species showing endo- and exoglucanase activities in the sediment from a mangrove located in Ilha do Cardoso, SP, Brazil were reported by Soares Junior et al. (2013). Also, the bacterium Bacillus sp. C1, isolated from cow dung, was found to possess good potential for endoglucanase production (Sadhu et al., 2013) while the cellulase-producing bacterium Micrococcus sp. SAMRCUFH3 was obtained from saw dust/wood shavings by Mmango-Kaseke $\boldsymbol{e t}$ al (2016). Cellulose forms the major component of plant cell wall along with hemicellulose and lignin and these complex polymeric compounds together form the bulk of the organic carbon in soil. Microorganisms are responsible for the recycling of this organic carbon in nature (Wang et al., 2008). Researchers have continuously searched for new microorganisms with higher cellulase production potential and hence important biotechnological applications (Ray et al., 2007).

\section{Characterization and identification of cellulolytic bacterium}

Cellulolytic bacterium was identified by using morphological, biochemical and physiological characterizations (Tab 2). The cells were Gram negative, rodshaped, non-spore forming and motile. It is an aerobic and catalase producing strain. It tested positive for gelatin hydrolysis, aesculin hydrolysis and could utilize a wide array of carbohydrates, including maltose, lactose, mannitol, raffinose and arabinose as sole source of carbon. From these various tests, isolate was tentatively identified as Enterobacter sp. Molecular characterization, based on 16S rRNA nucleotide sequencing and comparison to the sequences in NCBI database, was then carried out to confirm the identity of the bacterium as Enterobacter cloacae IP8 with maximum identity of $94 \%$ to other Enterobacter cloacae (Accession No. NR 118568.1).

\section{Bacterial growth and cellulase production}

The production of enzymes such as cellulase is often dependent on growth of the bacterium in the appropriate media. Cellulase production was evident in the culture supernatant after $8 \mathrm{~h}$ of incubation with the lag phase of $6 \mathrm{~h}$ during the incubation period. Enterobacter cloacae IP8 had a lag phase of about $6 \mathrm{~h}$. The peak of cellulase production was at $28 \mathrm{~h}$. The production of cellulase increased rapidly with increase in bacteria cell growth and peaked at the exponential phase followed by a decrease in cellulase production as the cell growth aged into the stationary phase. Results are shown in Figure 1. These results are similar to those reported by Prakash et al. (2008).

Table 1 Screening of cellulolytic bacteria for carboxymethyl cellulose hydrolytic capacity

\begin{tabular}{lccc}
\hline Isolate code & IP8 & IP15 & IP7 \\
\hline Diameter of zone of hydrolysis $(\mathrm{cm})$ & 2.8 & 3.5 & 3.1 \\
Hydrolytic capacity $(\mathrm{HC})$ value $(\mathrm{cm})$ & 4.7 & 1.7 & 1.3 \\
\hline
\end{tabular}

Table 2 Morphological, biochemical and physiological characteristics of $E$. cloacae IP8

\begin{tabular}{lc}
\hline Characteristics & Enterobacter cloacae IP8 \\
\hline Gram reaction & - \\
Morphology & $\mathrm{R}$ \\
Motility & + \\
Indole utilization & - \\
Methyl red test & - \\
Voges Proskauer & + \\
Citrate utilization & + \\
H2S production & - \\
Glucose & + \\
Maltose & + \\
Lactose & + \\
Mannitol & + \\
Raffinose & + \\
Arabinose & + \\
Sucrose & + \\
Coagulase test & + \\
Catalase test & - \\
Oxidase test & + \\
ONPG & - \\
Gelatin hydrolysis & + \\
Nitrate reduction & - \\
Esculin hydrolysis & +
\end{tabular}

Probable identity + = Positive; - = Negative; R = Rod

Enterobacter $\mathbf{s p .}$

\section{Optimization of fermentation conditions for cellulase production}

Optimum $\mathrm{pH}$ for cellulase synthesis from Enterobacter cloacae IP8 was 7.0 with enzyme activity $5.45 \pm 0.55 \mathrm{U} / \mathrm{mL}$ (Figure 2). A similar optimum $\mathrm{pH}$ of 7.0 was observed for cellulase production from Paenibacillus $s p$. isolated from molasses (Islam and Roy, 2018). However, optima $\mathrm{pH}$ of 5.0 was reported for cellulase production from E. cloacae WPL 214 isolated from bovine rumen fluid waste (Lokapirnasari et al., 2015). Cellulase activity was highest $(3.02 \pm 0.435 \mathrm{U} / \mathrm{mL})$ at temperature of $45{ }^{\circ} \mathrm{C}$ (Figure 3). Similar optimum temperature value was reported for cellulase secretion by a strain of E. cloacae (Lokapirnasari $\boldsymbol{e t}$ al., 2015). However, optimum temperature for cellulase production from a strain of Paenibacillus sp. was $45{ }^{\circ} \mathrm{C}$ (Islam and Roy, 2018). Temperature is a vital environmental factor which controls the growth and production of metabolites by microorganisms and this usually vary from one organism to another (Kumar and Takagi, 1999). During enzyme production at differing temperatures, stabilization of metabolic network is supposedly by the folding of proteins of the metabolic network itself, most probably by acquiring chaperones (Borges and Ramos, 2005).

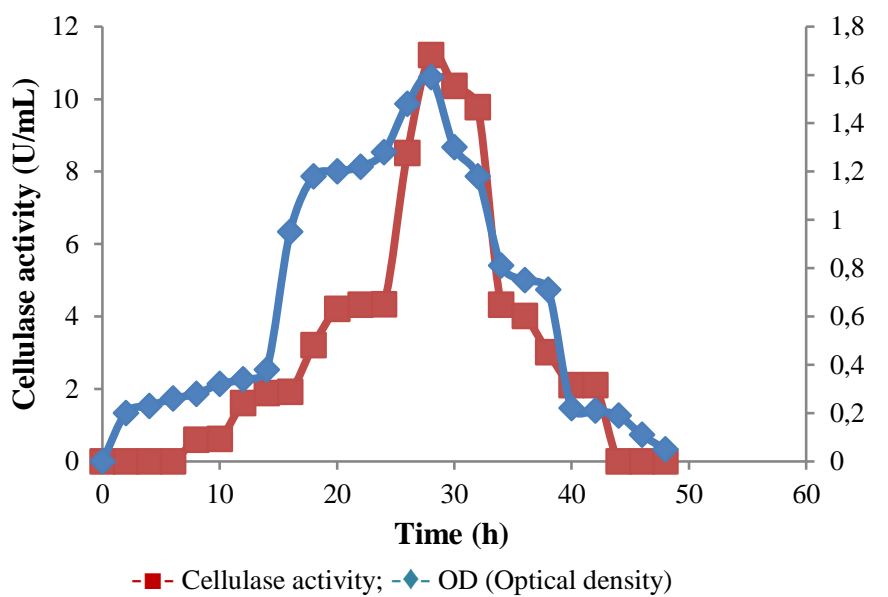

Figure 1 Growth and cellulase production of Enterobacter cloacae IP8 at 45 ${ }^{\circ} \mathrm{Cand} \mathrm{pH}$ 7.0. 


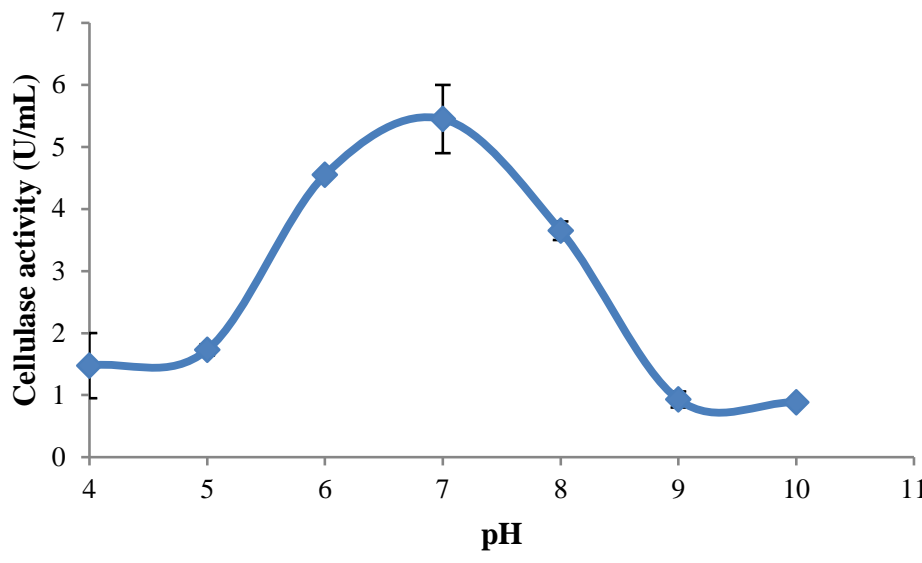

Figure 2 Effect of $\mathrm{pH}$ on cellulase production from Enterobacter cloacae IP8 at $45^{\circ} \mathrm{C}$

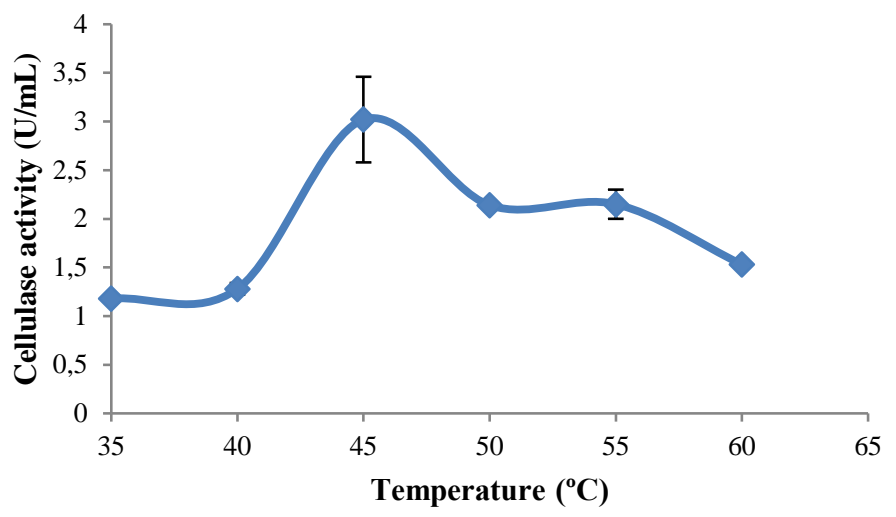

Figure 3 Effect of temperature on cellulose production from Enterococcus cloacae IP8 at $\mathrm{pH} 7.0$

Maximum cellulase yield was achieved with the use of CMC $(4.38 \pm 0.08 \mathrm{U} / \mathrm{mL})$ as carbon source followed by glucose $(2.78 \pm 0.02 \mathrm{U} / \mathrm{mL})$ (Figure 4). Therefore, the cellulase produced can be described as an inducible enzyme, whose production depends on the presence of the substrate which also acts as its inducer. Das et al. (2010) and Islam and Roy (2018) observed that CMC was the best carbon source for cellulase synthesis by thermophilic Bacillus species isolated from cow dung and Paenibacillus sp. isolated from molasses, respectively. The best CMC concentration for enzyme production was $1.5 \%, \mathrm{w} / \mathrm{v}$ (Figure 5). Cellulase production was most pronounced with the use of peptone $(3.51 \pm 0.38 \mathrm{U} / \mathrm{mL})$ as the nitrogen source in the fermentation medium (Figure 6). Peptone was also found to be the best nitrogen source for maximum cellulase production from Bacillus sp. Y3 (Lugani et al., 2015) and Bacillus sp. K1 (Paudel and Qin, 2015). The presence of external nitrogen source is essential in the fermentation medium during extracellular enzyme production for effective utilization of soluble carbohydrates (Ariffin et al., 2008). The use of organic nitrogen sources as compared to inorganic sources was found to be more suitable for maximum cellulase production (Ray et al., 2007).

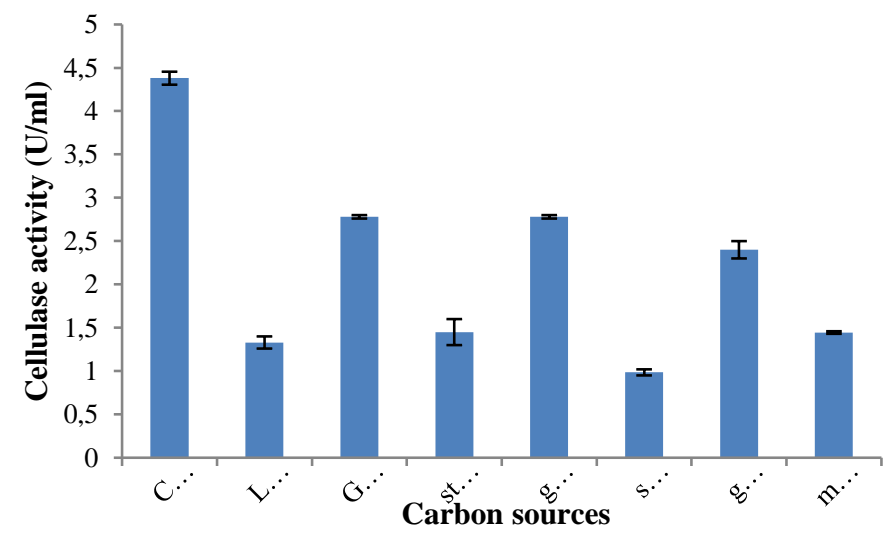

Figure 4 Effect of carbon sources on cellulase production from Enterobacter cloacae IP8

$\mathrm{CMC}=$ carboxymethyl cellulose

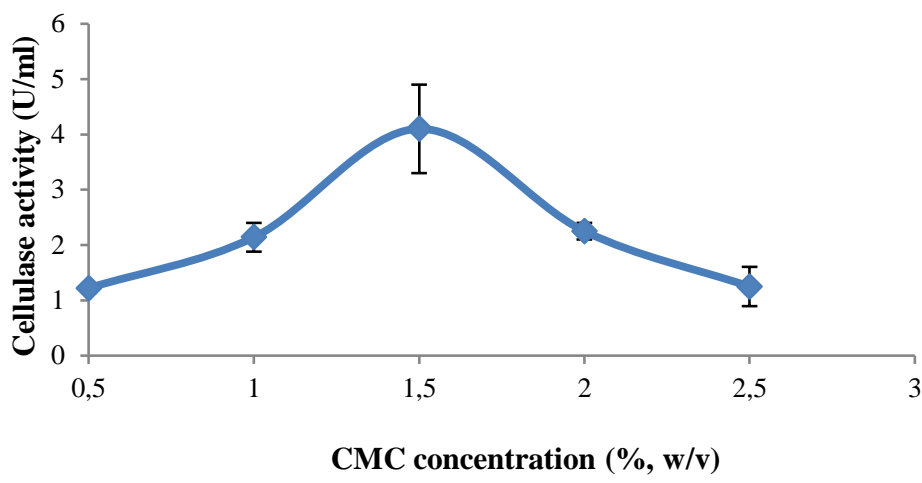

Figure 5 Effect of $\mathrm{CMC}$ concentration on cellulase production from Enterobacter cloacae IP8

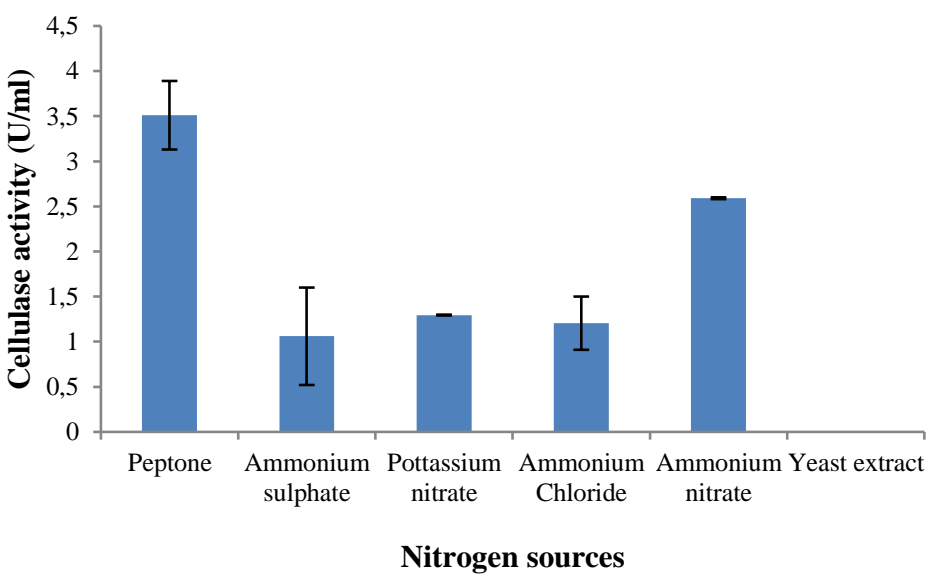

Figure 6 Effect of nitrogen sources on cellulase yield from Enterobacter cloacae IP8

Physicochemical properties of crude cellulase from E. cloacae IP8

Effect of $p H$ on the activity and stability of crude cellulase from E. cloacae IP8

The activity of crude cellulase from E. cloacae IP8 was determined at different $\mathrm{pH}$ range 4.0 to 9.0 . The crude cellulase exhibited activity at broad $\mathrm{pH}$ range 4.0 to 9.0 with optimum activity being at the $\mathrm{pH} 7.0$ (Figure 7). It retained $58.0 \%$ of its maximal activity at acidic $\mathrm{pH} 5.0$. This enzyme can therefore be classified as being active at acid to neutral $\mathrm{pH}$. Similar optimum activity were also found at pH 7.0 for cellulase from Cellulomonas sp. YJ5 (Yin et al. (2010) and Bacillus vallismortis RG-07 (Gaur and Tiwari, 2015). However, optima $\mathrm{pH}$ of 5.0 and 9.0 were reported for cellulase from Bacillus licheniformis 380 (De Marco et al., 2017) and B. licheniformis Vic. (Kilo et al., 2016), respectively. Increasing or decreasing the $\mathrm{pH}$ changes the ionic state of ionizing side chains in a protein, distrupts ion pairs, breaks hydrogen bond, and consequently denatures the protein (Rawn, 1989). Cellulases are generally stable over a wide range of $\mathrm{pH}$ from 5.0 to $10.0(\mathrm{Kim}$ et al., 2005; Tahir et al., 2009).

Effect of temperature on the activity and stability of crude cellulase from $E$. cloacae IP8

The activity of crude cellulase from E. cloacae IP8 was determined at different temperatures ranging from $35^{\circ} \mathrm{C}$ to $80{ }^{\circ} \mathrm{C}$. The results showed that the enzyme had optimum activity at $60{ }^{\circ} \mathrm{C}$ (Figure 8). The enzyme retained $75 \%$ of its maximal activity at $70{ }^{\circ} \mathrm{C}$. Optimum activity of the enzyme obtained at $60{ }^{\circ} \mathrm{C}$ indicates that the cellulase from E. cloacae IP8 was relatively thermostable. Above $70{ }^{\circ} \mathrm{C}$, cellulase activities decreased sharply. The obtained result from the present study is similar to the findings of Yin et al. (2010) and De Marco et al., (2017) on cellulase from Cellulomonas sp. YJ5 and Bacillus licheniformis 380, respectively, which had optimum temperature of $60{ }^{\circ} \mathrm{C}$. However, lower optima temperatures of $35{ }^{\circ} \mathrm{C}$ and $50{ }^{\circ} \mathrm{C}$ were reported of cellulases from a strain of Pseudomonas fluorescence (Bakare et al. 2005) and Bacillus licheniformis C55 (Listyaningrum et al., 2018), respectively. Cellulase from E. cloacae IP8 thus exhibited relatively higher optimum temperature for activity and good thermal stability. These properties are very important for cellulose saccharification and may make the enzyme suitable for application to several biotechnological and industrial purposes. 


\section{Effect of metal ions and EDTA on the activity of crude cellulase from $E$.} cloacae IP8

The effect of various metal ions on the crude cellulase from E. cloacae IP8 was tested (Figure 9). The cations $\mathrm{Ca}^{2+}$ and $\mathrm{Na}^{+}$exhibited stimulatory effects on the enzyme activity in all range of concentrations (Figure 9). While $\mathrm{Mg}^{2+}$ concentrations $4 \mathrm{mM}$ to $15 \mathrm{mM}$ inhibited the activity of the enzyme, it stimulated its activity from concentrations $20 \mathrm{mM}$ to $200 \mathrm{mM}$ (Figure 9). The stimulatory effect of $\mathrm{Na}^{+}$and $\mathrm{Ca}^{2+}$ on cellulase activity had been reported by Femi-Ola and Olowe (2011) and Gaur and Tiwari (2015) which is similar to the finding of this study. The cation $\mathrm{K}^{+}$exhibited inhibitory effect against cellulase activity accross all range of concentrations up to $200 \mathrm{Mm}$ (Figure 9). This results show that cellulase from E. cloacae IP8 is metal ion dependent. EDTA at concentrations above $4 \mathrm{mM}$ was inhibitory to the activity of the crude cellulase from the bacterium (Figure 9). The result of this study is in agreement with the reported inhibitory effect of EDTA on cellulase activity by Oikawa $\boldsymbol{e t}$ al. (1994). EDTA as a metal chelating agent probably acts by inactivating the cellulase either by removing metal ions from the enzyme through the formation of coordinating complex or binding inside the enzyme as a ligand, as had been noted by Schmid (1997).

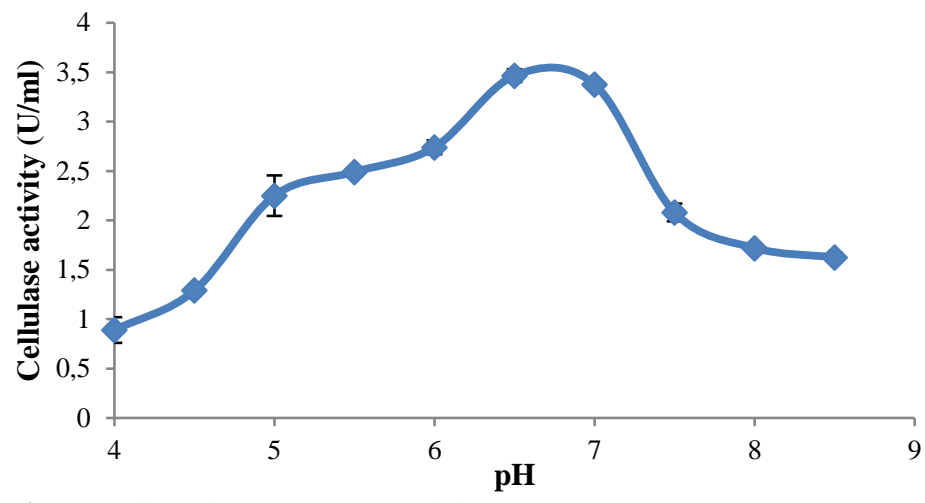

Figure 7 Effect of $\mathrm{pH}$ on cellulase activity

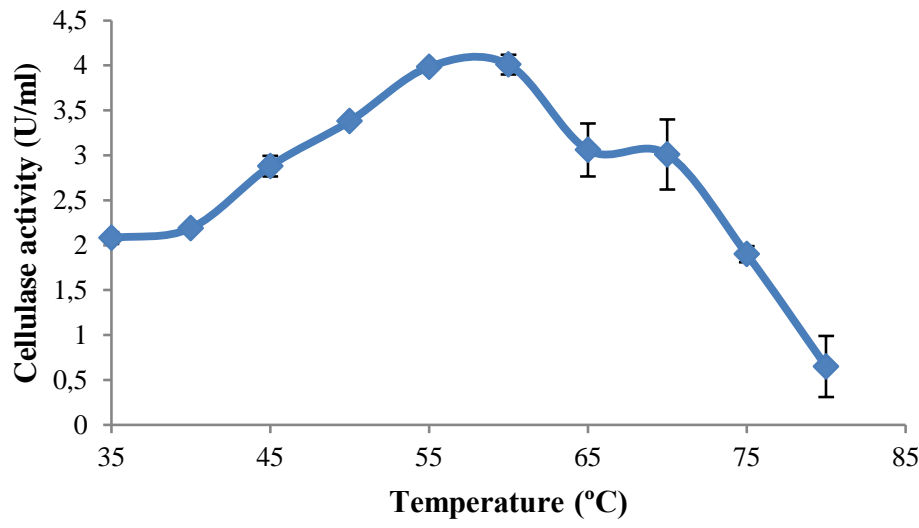

Figure 8 Effect of temperature on cellulase activity

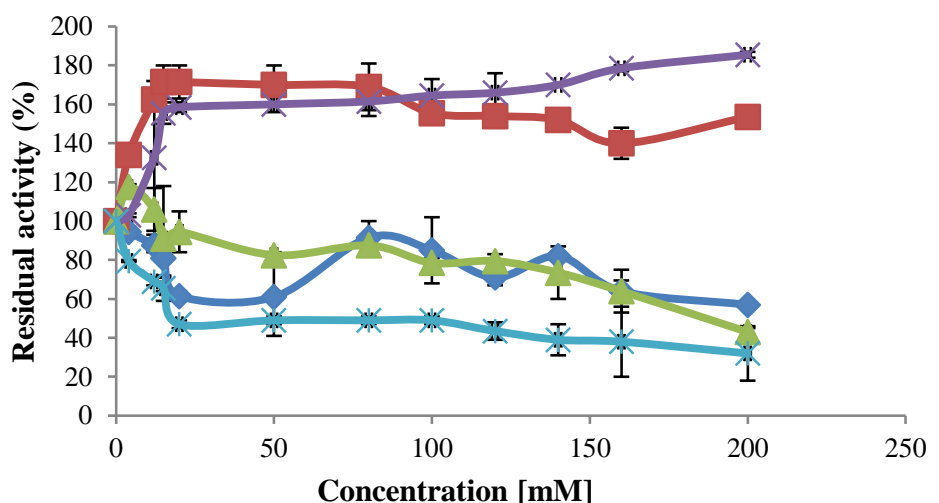

$-\downarrow-\mathrm{K}^{+} ;-\mathbf{-}-\mathrm{Na}^{+} ;-\triangle-\mathrm{Mg}^{2+} ;-\times-\mathrm{Ca}^{2+} ;-*-\mathrm{EDTA}$

Figure 9 Effect of metal ions and EDTA on cellulase activity

\section{CONCLUSION}

In this study, Enterobacter cloacae IP8 was successfully isolated from plant leaf litters of Lagerstroemia indica L. Enhanced production of cellulase by the bacterium was achieved at $\mathrm{pH}$ and temperature conditions 7.0 and $45{ }^{\circ} \mathrm{C}$, respectively and with the use of carboxymethyl cellulose and peptone as carbon and nitrogen sources, respectively. The crude cellulase of this isolate exhibited its optimum activity at $\mathrm{pH}$ of 7.0 and temperature of $60{ }^{\circ} \mathrm{C}$. The enzyme was stimulated by $\mathrm{Ca}^{2+}, \mathrm{Na}^{+}$and $\mathrm{Mg}^{2+}$ while $\mathrm{K}^{+}$reduced its activity. Because of its activity and stability at high temperatures, cellulase of Enterobacter cloacae IP8 isolated in this study has promising potentials for biotechnological and industrial applications. However, further studies on optimization of cost-effective substrate for bulk production of enzyme and protein engineering for more thermostable enzyme with even more turn over and specific activity are needed.

Acknowledgments: Authors appreciate the Departments of Microbiology and Biochemistry and Molecular Biology, Obafemi Awolowo University, Ile-Ife, Nigeria for provision of chemical reagents and equipments used.

\section{REFERENCES}

ACOSTA-RODRIGUEZ, I., PINON-ESCOBEDO, C., ZAVALA-PARAMO, M G., LOPEZ-ROMERO, E., CANO-CAMACHO, H. (2005). Degradation of cellulose by the bean-pathogenic fungus Colletotrichum lindemuthianum. Production of extracellular cellulolytic enzymes by cellulose induction. Antonie Van Leeuwenhoek 87, 301-310. http://dx.doi.org/10.1007/s10482-004-6422-6 ACHARYA, S., CHAUDHURY, A. (2012). Bioprospecting hermophiles for cellulase production: A review. Braz. J. Microbiol. 43(3), 844-856. http://dx.doi.org/10.1590/S1517-83822012000300001

APUN, K., JONG, B. C., SALLEH, M. A. (2000). Screening and isolation of a cellulolytic and amylolytic Bacillus from sago pith waste. J. Gen. Appl. Microbiol. 46, 263-267. http://dx.doi.org/10.2323/jgam.46.263

ARIFFIN, H., HASSAN, M. A., SHAH, U. K., ABDULLAH, N., GHAZALI, F. M., SHIRAI, Y. (2008). Production of bacterial endoglucanase from pretreated oil palm empty fruit bunch by Bacillus pumilus EB3. J. Biosci. Bioeng. 106, 231236. http://dx.doi.org/10.1263/jbb.106.231

BAKARE, M. K., ADEWALE, I. O., SHONUKAN, O. O. (2005). Purification and characterization of cellulase from the wild type and two improved mutants of Pseudomonas fluorescens. Afr. J. Biotechnol. 4(9), 898-904.

BEHERA, B. C., SETHI, B. K., MISHRA, R. R., DUTTA, S. K., THATOI, H. N. (2017). Microbial cellulases - Diversity \& Biotechnology with reference to mangrove environment: A review. J. Genetic Eng. Biotechnol. 15, 197-210. http://dx.doi.org/10.1016/j.jgeb.2016.12.001

BHAT, M. K. (2000). Cellulases and related enzymes in biotechnology. Biotechnol. Adv. 18, 355-383. http://dx.doi.org/10.1016/S0734-9750(00)00041-0 BORGES, J. C., RAMOS, C. H. I. (2005). Protein folding assisted by chaperones. Protein Pep. Lett. 12, 257-261. http://dx.doi.org/10.2174/0929866053587165

CHEN, M., XIA, I., XUE, P. (2007). Enzymatic hydrolysis of corncob and ethanol production from cellulosic hydrolysate. Int. Biodeter. Biodegrad. 59, 8589. http://dx.doi.org/10.1016/j.ibiod.2006.07.011

DAS, A., BHATTACHARYA, S., MURALI, L. (2010). Production of cellulase from a thermophilic Bacillus sp. isolated from cow dung. American-Eurasian $J$. Agric. Environ. Sci. 8(6), 685-691.

DE CARVALHO, L. M. J., DE CASTRO, I. M., DA SILVA, C. A. B. (2008). A study of retention of sugars in the process of clarification of pineapple juice (Ananas comosus L. Merril) by micro- and ultra-filtration. J. Food Eng. 87, 447454. http://dx.doi.org/10.1016/j.jfoodeng.2007.12.015

DE MARCO, E. G., HECK, K., MARTOS, E. T., VAN DER SAND, S. T. (2017). Purification and characterization of a thermostable alkaline cellulase produced by Bacillus licheniformis 380 isolated from compost. Annal. Braz. Acad. Sci. 89(3), 2359-2370. http://dx.doi.org/10.1590/0001-396520170408

DE SOUZA, A. N., MARTINS, M. L. L. (2001). Isolation, properties and kinetics of growth of a thermophilic Bacillus. Braz. J. Microbiol. 32, 271-275. http://dx.doi.org/10.1590/S1517-83822001000400003

DOI, R. H. (2008). Cellulase of mesophilic microbes: cellulosome and noncellulosome producers. Ann New York Academic of Science. 1125, 267-279. http://dx.doi.org/10.1196/annals.1419.002

EVELEIGH, D. E., BOK, J. D., EL-DORRY, H. S., EL-GOGARY, K., ELLISTON, A., GOYAL, C., WALDRON, R., WRIGHT, WU, Y. M. (2005) Cellulase lessons revealed through the microbe's perspective. Appl. Biochem. Biotechnol. 51-52(0), 169-177.

FEMI-OLA, T. O., OLOWE, B. M. (2011). Characterization of alpha amylase from Bacillus substilis BS5 isolated from Amistermes evuncifer Silvestri. Res. J. Microbiol. 6(2), http://dx.doi.org/10.3923/jm.2011.140.146

GAO, Z., XIAO, J., WANG, X., RUAN, L., CHEN, X., ZHANG, Y. (2012) Vibrio xiamenensis sp. nov., a cellulase-producing bacterium isolated from mangrove soil. Int. J. Syst. Evol. Microbiol. 62, 1958-1962. http://dx.doi.org/10.1099/ijs.0.033597-0 
GAUR, R., TIWARI, S. (2015). Isolation, production, purification and characterization of an organic-solvent-thermostable alkalophilic cellulase from $\begin{array}{lllll}\text { Bacillus vallismortis RG-07. BMC Biotechnol. } 15, & 19 .\end{array}$ http://dx.doi.org/10.1186/s12896-015-0129-9

GILNA, V.V., KHALEEL, K.M. (2011). Cellulase enzyme activity of Aspergillus fumigatus from mangrove soil on lignocellulosic substrates. Recent Research in Science and Technology, 3(1), 132-134.

HARRIGAN, F.W., MCCANCE, E.M. (1976). Laboratory Methods in Food and Dairy Microbiology. Academic Press, London. pp 33-200.

HIKARU, N., KATSUNORI, O., RYOTA, K., TETSUYA, K., TOMOKO, O., NOBUHIRO, O., NAOKI, O., WATARU, O., HIROFUMI, O., YASUSHI, M (2008). Characterisation of the catalytic domain of Trichoderma reesei endoglucanase I, II and III expressed in Escherichia coli. Appl. Microbiol. Biotechnol. 81 ,

681-689. http://dx.doi.org/10.1007/s00253-008-1667-z

IMMANUEL, G., DHANUSHA, R., PREMA, P. PALAVESAM, A. (2006) Effect of different growth parameters on endoglucanase enzyme activity by bacteria isolated from coir retting effluents of estuarine environment. Int. J. $\begin{array}{llll}\text { Environ. } & \text { Sci. } & \text { Technol. } & 3(1),\end{array}$ http://dx.doi.org/10.1007/BF03325904

ISLAM, F., ROY, N. (2018). Screening, purification and characterization of cellulase from cellulase-producing bacteria in molasses. BMC Res. Notes. 11 445. http://dx.doi.org/10.1186/s13104-018-3558-4

KARNAOURI, A. C, TOPAKAS, E., CHRISTAKOPOULOS, P. (2014) Cloning, expression, and characterization of a thermostable GH7 endoglucanase from Myceliophthora thermophila capable of high-consistency enzymatic liquefaction. Appl Microbiol Biotechnol. 98(1), 231-242. http://dx.doi.org/10.1007/s00253-013-4895-9

KILO, I. K., JACKIM, M. F., MUNYAH, W. B., MUGE, E. K. (2016). Isolation and characterization of a thermostable cellulase from Bacillus licheniformis strain Vic. isolated from a geothermal wells in the Kenyan rift valley. The Open Biotechnol. J. 10, 198-207. http://dx.doi.org/10.2174/1874070701610010198

KIM, J. Y., HUR, S. H., HONG, J. H. (2005). Purification and characterization of an alkaline cellulase from a newly isolated alkalophilic Bacillus sp. HSH-810. Biotechnol. Lett. 27, 313-316. http://dx.doi.org/10.1007/s10529-005-0685-5

KUHAD, R. C., GUPTA, R., SINGH, A. (2011). Microbial cellulases and their industrial applications. Enzyme Res. 2011, 1-10. http://dx.doi.org?10.4061/2011/280696

KUMAR, C. G., TAKAGI, H. (1999). Microbial alkaline proteases: from a bio industrial view point. Adv. Biotechnol. 17, 561-594. http://dx.doi.org/10.1016/S0734-9750(99)00027-0

LADEIRA, S. A., CRUZ, E., DALATORRE, A. B., BARBOSA, J. B., MARTINS, M. I. I. (2015). Cellulase production by thermophilic Bacillus sp. SMIA-2 and its detergent compatibility. Electron. J. Biotechnol. 18, 110-115. http://dx.doi.org/10.1016/j.ejbt.2014.12.008

LISTYANINGRUM, N. P., SUTRISNO, A., WARDANI, A. K. (2018). Characterization of thermostable cellulase produced by Bacillus strains isolated from solid waste of carrageenan. IOP. Conf. Series: Earth Environ. Sci. 131, 1-7. http://dx.doi.org/10.1088/1755-1315/131/1/012043

LOKAPIRNASARI, W. P. NAZAR, D. S. NURHAJATI, T., SUPRANIANONDO, K., YULIANTO, A. B. (2015). Production and assay of cellulolytic enzyme activity of Enterobacter cloacae WPL 214 isolated from bovine rumen fluid waste of Surabaya abbatoir, Indonesia. Vet. World 8(3), 367371. http://dx.doi.org/10.14202/vetworld.2015.367-371

LU, W.J., WANG, H.T., YANG, S.J., WANG, Z.C., NIE, Y.F. (2005). Isolation and characterization of mesophilic cellulose degrading bacteria from flower stalks vegetable waste co-composting system. J. Gen. Appl. Microbiol. 51, 353 360. http://dx.doi.org/10.2323/jgam.51.353

LUGANI, Y., SINGLA, R. SOOCH, B. S. (2015). Optimization of cellulase production from newly isolated Bacillus sp. Y3. J. Bioprocess. Biotech. 5(11), 264. http://dx.doi.org/10.4172/2155-9821.1000264

MAKOI, J.H.J.R., NDAKIDEMI, P.A. (2008). Selected soil enzymes: examples of their potential roles in the ecosystem. Afr. J. Biotechnol. 7, (3), 181-191.

MANGAMURI, U. K., MUVVA, V., PODA, S., KAMMA, S. (2012). Isolation, identification and molecular characteristics of rare actinomycetes from mangrove ecosystem of Nizampatnam. Malays. J. Microbiol. 8, 83-91.

MMANGO-KASEKE, Z., OKAIYETO, K., NWODO, U. V., MABINYA, L. V., $\mathrm{OKOH}$, A. I. (2016). Optimization od cellulase and xylanase production by Micrococcus species under submerged fermentation. Sustain. 8, 1168 http//dx.doi.org/10.3390/su8111168

NAGENDRAN, S., HALLEN-ADAMS, H. E., PAPER, J. M., ASLAM, N., WALTON, J. D. (2009). Reduced genomic potential for secreted plant cell wall degrading enzymes in the ectomycorrhical fungus Amanita bisporigera, based on the secretome of Trichoderma reesei. Fungal Gene Biol. 46, 427-435 http://dx.doi.org/10.1016/i.fgb.2009.02.001

NARASIMHA, G., SRIDEVI, A., BUDDOLlA, V., SUBHOSH, C. M., RAJASEKHAR, R. B. (2006). Nutrient effects on production of cellulolytic enzymes by Aspergillus niger. Afr. J. Biotechnol. 5(5), 472-476.

OIKAWA, T., TAKAGI, M., AMEYAWA, M. (1994). Detection of carboxylmethylcellulase activity in Acetobacter xylinum $\mathrm{Ku}-1$. Biosci
Biotechnol.

Biochem.

58

$2102-2103$

http://dx.doi.org/10.1271/bbb.58.2102

OMOJASOLA, P.F., JILANI, O.P. (2008). Cellulase production by Trichoderma longi, Aspergillus niger and Saccharomyces cerevisae cultured on waste materials from orange. Pakistan J. Biol. Sci. 11(20), 2382-2388. http://dx.doi.org/10.3923/pjbs.2008.2382.2388

PARRY, N. J., BEEVER, D. E., OWEN, E., I. VANDNBERHE, I., BEEUMEN, J.V AND M. BHAT, M. (2001). Biochemical characterization and mechanism of action of thermostable $\beta$-glucosidase purified from Thermoasus aurantiacus

353

117-127.

http://dx.doi.org/10.1042/bj3530117

PAUDEL, Y. P., QIN, W. (2015). Characterization of novel cellulase-producing bacteria isolated from rotting wood samples. Appl. Biochem. Biotechnol. 177, 1186-1198. http://dx.doi.org/10.1007/s12010-015-1806-9

PRAKASH, B., VIDYASAGAR, M., MADHUKUMAR, M. S., MURALIKRISHNA, G., SREERAMULU, K. (2008). Production, purification and characterization of two extremely halotolerant, thermostable, and alkalistable $\alpha$-amylases from Chromohalobacter sp. TVSP 101. Process Biochem. 44 210-215. http://dx.doi.org/10.1016/j.procbio.2008.10.013

RAY, A. K., BAIRAGI, A., GHOSH, K. S., SEN, S. K. (2007). Optimization of fermentation conditions for cellulase production by Bacillus subtilis CY5 and Bacillus circulans TP3 isolated from fish gut. Acta Ichthyol. Lett. 1, 47-53. http://dx.doi.org/10.3750/AI.2007.3.7.1.07

RAWN, J. D. (1989). Biochemistry. $1^{\text {st }}$ Ed. Neil Patterson Publishers, Burlington, NC., U.S.A. pp 341-406.

REDDY, G. P. K., NARASIMHA, G., KUMAR, K. D., RAMANJANEYULU, G., RAMYA, A., KUMARI, B. S. S., REDDY, B. R. (2015). Cellulase production by Aspergillus niger in different natural lignocellulosic substrates. Int J. Current Microbiol. Appl. Sci. 4, 835-845.

SADHU, S., SAHA, P., SEN, S. K., MAYILRAJ, S., MAITI, T. K. (2013). Production, purification and characterization of a novel thermotoleran endoglucanase (CMCase) from Bacillus strain isolated from cow dung. SpringerPlus 2: 1-10. http://dx.doi.org/10.1186/2193-1801-2-10

SCHMID, F.X. (1997). Optical spectroscopy to characterize protein conformation and conformational changes. In: Protein structure: A practica approach 2nd ed. (T.E Creighton, ed). TRL Press, Oxford, New York and Tokyo. pp 360

SOARES JUNIOR, F. L., DIAS, A. C. F., FASANELLA, C. C., TAKETANI, R. G., LIMA, A. O. D., MELO, I. S., ANDREOTE, F. D. (2013). Endo- and exoglucanase activities in bacteria from mangrove sediment. Braz. J. Microbiol. 44(3), 969-976. http://dx.doi.org/10.1590/S1517-838220130003000048

SOMOGYI, M. (1952). Notes on sugar determination. J. Biol. Chem. 194, 19-24. TAHIR, S. R., BAKSH, A., RAO, A. Q., NAZ, M., SALEEM, M. (2009). Isolation, purification and characterization of extracellular $\beta$-glucosidase from Bacillus sp. Adv. Environ. Biol. 3(3), 269-277.

WANG, C.M., SHYU, C.L., HO, S.P., CHIOU, S.H. (2008). Characterization of a novel thermophilic cellulose-degrading bacterium Paenibacillus sp. strain B39. $\begin{array}{llll}\text { Lett. } & \text { Appl. } & \text { Microbiol. } & \text { 47(1), }\end{array}$ http://dx.doi.org/10.1111/j.1472-765X.2008.02385.x

WOOD, T. M., BHAT, M. K. (1988). Methods for measuring cellulase activities. In, Methods in Enzymology (Wood, A., Kellogg, S. T., Ed.) Academic press Inc., London,
http://dx.doi.org/10.1016/0076-6879(88)60109-1

YIN, L. J., HUANG, P. S., LIN, H. H. (2010). Isolation of cellulase-producing bacteria and characterization of the cellulase from the isolated bacterium Cellulomonas sp. YJ5. J. Agric. Food Chem. 58, 9833-9837. http://dx.doi.org/10.1021/jf1019104 